\title{
Uric acid clearance in patients with gout and normal subjects
}

\author{
M. L. SNAITH* AND J. T. SCOTT \\ Kennedy Institute of Rheumatology and West London Hospital, Hammersmith, London, W.6
}

The causes of hyperuricaemia in so-called primary gout remain undetermined. Only a proportion of patients has been shown by studies of isotope dilution (Seegmiller, Grayzel, Laster, and Liddle, 1961) or of urinary excretion (Gutman and Yü, 1957) to produce excessive quantities of uric acid, but it is generally thought that uric acid clearance in most patients with gout does not differ markedly from that found in normal subjects (Gutman and Yü, 1957). Opinions on this subject have not been unanimous, however, and we have therefore reexamined the uric acid clearance figures in a number of gouty subjects, comparing them with a control group.

\section{Patients and methods}

The gouty patients consisted of men attending a clinic devoted exclusively to this disease. All had a history of acute gouty arthritis and some had chronic joint changes, but there was no selection for study on the basis of disease severity, tophi, chronic joint damage, renal disease, or stone formation. Their mean age was 49 years (range 21 to 78). The control group of 46 men (mean age 43 years, range 20 to 69) consisted of members of staff and of patients attending the West London Hospital (mostly in-patients, or out-patients attending the orthopaedic, physical medicine, or neurological clinics). None had overt renal, cardiovascular, or other disease known to affect uric acid metabolism and none gave a family history of gout. No subject was taking drug therapy which might affect urate levels in blood or urine. The nature of the study was carefully explained to all participants and their full co-operation was obtained.

A standard, alcohol-free, low-purine diet providing less than $300 \mathrm{mg}$. purine daily was taken by all subjects for at least 4 days before, and then throughout, a period of three successive 24-hr urine collections. The specimens were collected in plastic bottles containing toluene as a preservative and immediately delivered to the laboratory. There were no restrictions on fluid intake. Daily blood samples were taken during the 3-day period.

Plasma and urinary uric acid were estimated by an enzymatic spectrophotometric method (Liddle, Seegmiller, and Laster, 1959), using commercially prepared uricase (Leo Laboratories, Ltd.). Plasma and urinary creatinine were measured in the same Unicam spectrophotometer by the method described by Edwards and Whyte (1958). The 24-hr clearance values were corrected to a standard body surface area of $1 \cdot 73 \mathrm{~m}^{2}$.

\section{Results}

All results are given as the means of three daily values.

\section{(1) CREATINiNe ClearanCe (Fig. 1)}

The rather lower clearance shown by some of the gouty patients resulted in a difference between the groups as a whole $(0.005<P<0.01)$ which is statistically significant but not marked.

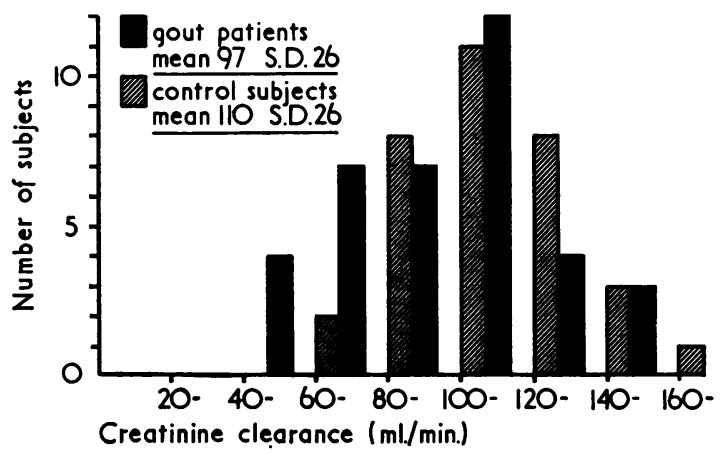

FIG. 1 Creatinine clearance in gouty patients and control subjects.

(2) PLASMA URIC ACID (Fig. 2, overleaf)

As expected, the two groups are quite sharply demarcated although there is some overlap, with figures for control subjects extending up to $7.4 \mathrm{mg}$./ $10 \mathrm{ml}$. 


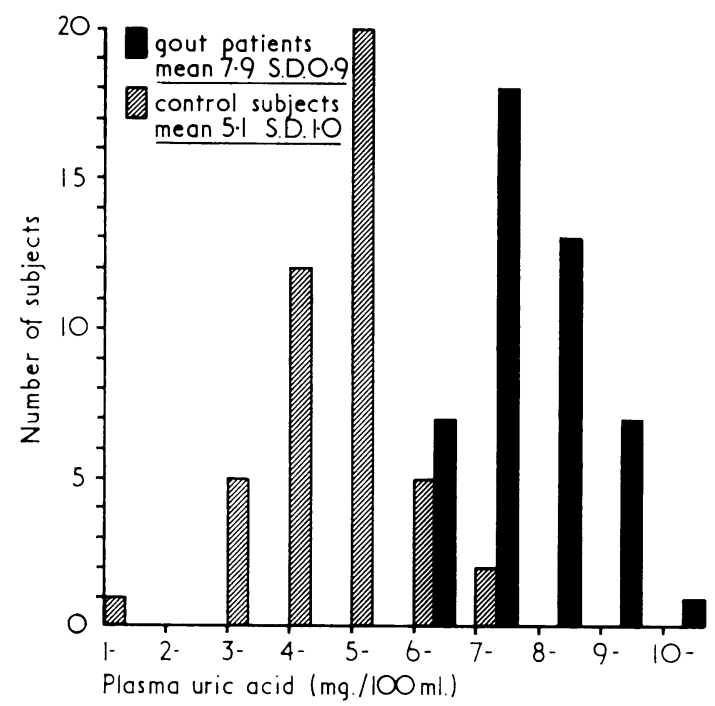

FIG. 2 Plasma uric acid in gouty patients and control subjects.

(3) LRINARY URIC ACID (Fig. 3)

Here the overlap is considerable, with the majority of gouty subjects falling into the normal range. The mean value for gouty patients $(514 \mathrm{mg} . / 24 \mathrm{hrs})$ is only slightly greater than that for the controls (479 mg. 24 hrs; $0 \cdot 1>\mathrm{P}>0 \cdot 15$ ).

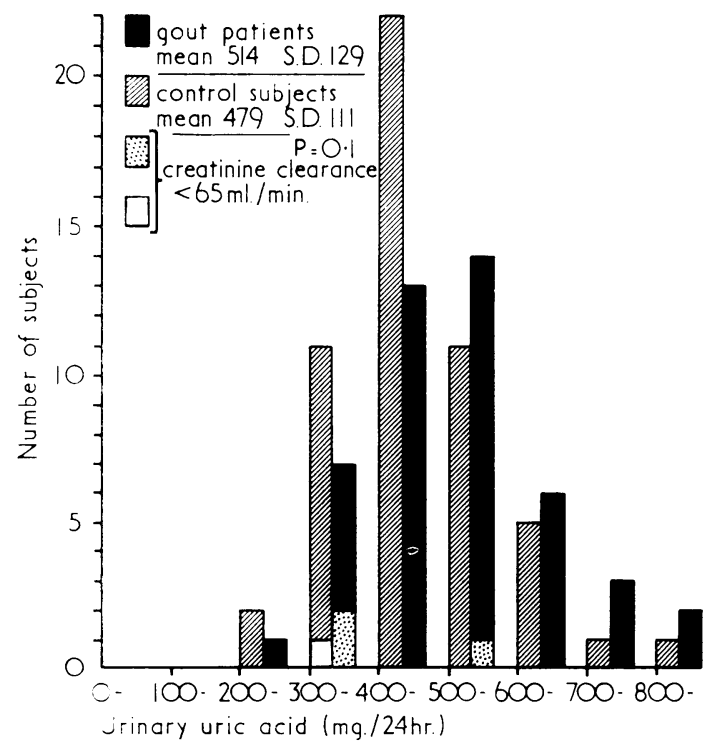

FIG. 3 24-hr urinary uric acid excretion in gouty patients and control subjects.

(4) URIC ACID CLEARANCE (Fig. 4)

Clearance values for gout patients (mean $3.6 \mathrm{ml}$. min.: S.D. $1 \cdot 3$ ) were substantially lower than that of the controls (mean $5.8 \mathrm{ml} / \mathrm{min}$; S.D. 2.1), a highly significant difference $(\mathrm{P}<0 \cdot 001)$.

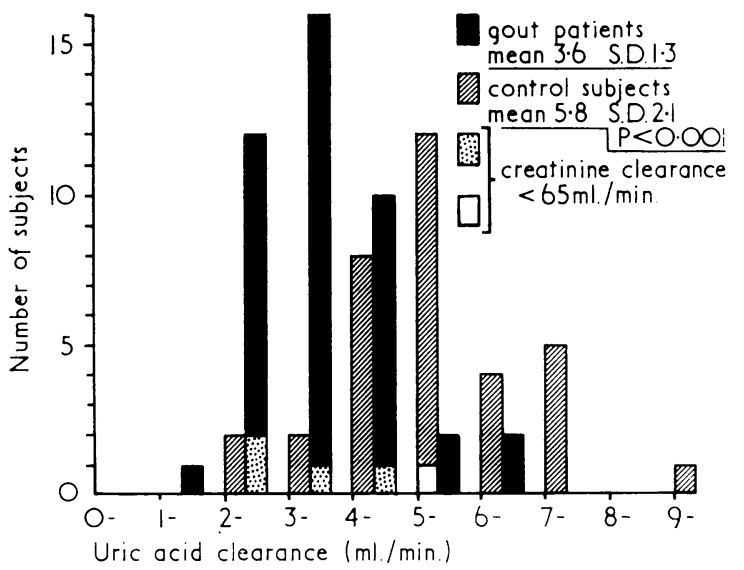

FIG. 4 Uric acid clearance in gouty patients and contro subjects.

(5) URIC ACID: CREATININE CLEARANCE

RATIO (Fig. 5)

Differences between creatinine clearance of the $\vec{\varphi}$ two groups being only slight, the lower uric acid clearance of the gouty patients is also reflected in a comparison of uric acid and creatinine clearances.

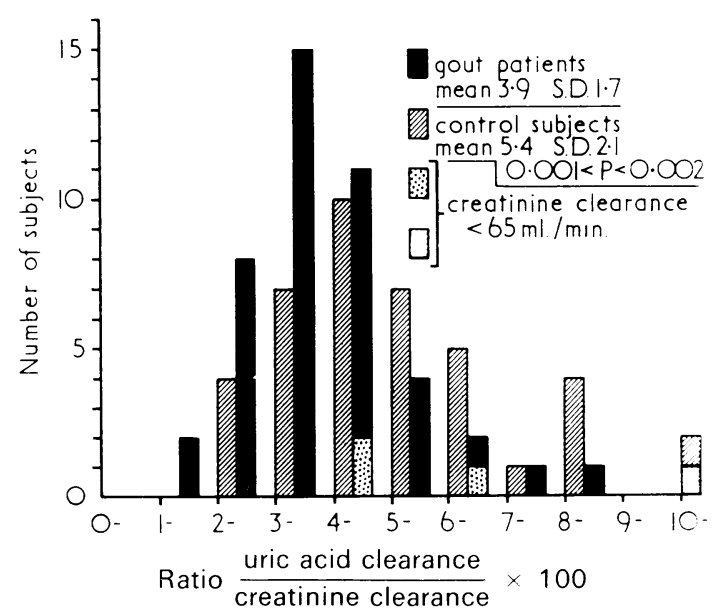

FIG. 5 Uric acid clearance

Creatinine clearance

102

ratio in gouty patients and control subjects.

(6) URINARY URIC ACID: CREATININERATIO (Fig. 6, opposite)

There was no significant difference between the two groups, with almost identical ranges, means. and standard deviations.

\section{Discussion}

In the study of Gutman and Yü (1957), little difference was found between the mean levels of 


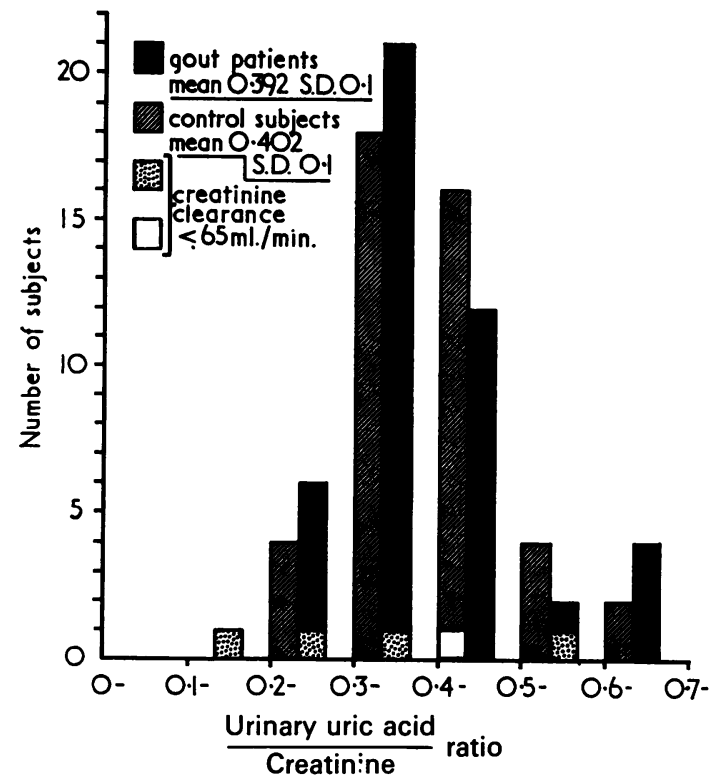

FIG. 6 Urinary $\frac{\text { uric acid }}{\text { creatinine }}$ ratio in gouty patients and control subjects.

uric acid clearance in gouty patients $(7.5 \mathrm{ml} . / \mathrm{min}$.) and those of control subjects $(8.7 \mathrm{ml} . / \mathrm{min}$.). The mean clearance of the gouty patients was thus 86 per cent. of the control value. Following this, a number of studies attempted to assess the effect of added loads of uric acid in gouty and normal subjects and it became evident that both groups were able to increase their rate of clearance in such circumstances (Nugent and Tyler, 1959; Lathem and Rodnan, 1962; Gutman, Yü, and Berger, 1969). Data from the present study, however, indicate a rather greater difference in mean clearance figures, values for gouty patients $(3.9 \mathrm{ml} . / \mathrm{min}$.) being only 70 per cent. of those for control subjects $(5.8 \mathrm{ml}$./ min.). This greater difference is consistent with that found by some other investigators (Table).

Clearance figures in the present investigation have been corrected for surface area, as is accepted practice (Thompson and Wootton, 1970). This is relevant because gouty patients tend to be rather more obese than normal subjects. The relation of height to weight may be expressed by the ponderal index (Evans, Prior, and Harvey, 1968):

$$
\frac{\text { height in inches }}{\sqrt[3]{\text { weight in pounds }}}
$$

The ponderal index in gouty patients and normal subjects is shown in Fig. 7. The mean value for gouty patients $(12 \cdot 1)$ is significantly $(P<0.005)$ lower than that of control subjects $(12 \cdot 7)$, i.e. they tend to be more obese for their height.

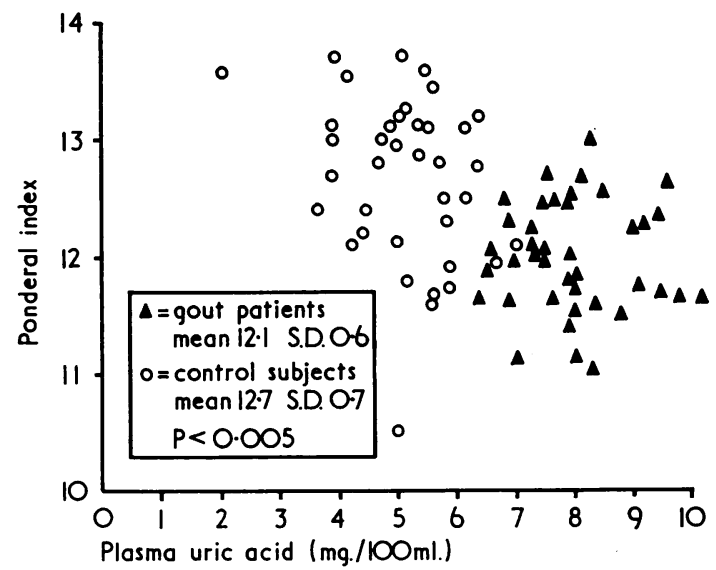

FIG. 7 Ponderal index in gouty patients and control subjects.

It is not clear why the difference in uric acid clearance between gouty patients and control subjects in the present study is rather greater than that of Gutman and Yü (1957). It is possible that populations of gouty patients are different: for example, an extensive referral of patients with renal uric acid stones (who tend to have a high excretion rate of uric acid) would raise the mean clearance figures of uric acid in a group under study. In this connection, the incidence of nephrolithiasis in gout of 22 per cent. given by Gutman and Yü (1968) is considerably higher than the total of 11 per cent. giving a history suggestive of stone formation in our experience (Grahame and Scott, 1970). Only ten patients with gout had a urinary excretion of more than $600 \mathrm{mg}$. uric acid daily, and none over $900 \mathrm{mg}$. Seven normal subjects excreted more than $600 \mathrm{mg}$.

Table Uric acid clearance ( $\mathrm{ml}$./min.) reported by five authors in gouty subjects and normal controls

\begin{tabular}{|c|c|c|c|c|c|c|}
\hline \multirow[t]{2}{*}{ Authors } & \multirow[t]{2}{*}{ Date } & \multirow[t]{2}{*}{ Place } & \multicolumn{2}{|c|}{ Gout } & \multicolumn{2}{|c|}{ Control } \\
\hline & & & No. & Mean $C U A$ & No. & Mean $C U A$ \\
\hline $\begin{array}{l}\text { Gutman and Yü } \\
\text { Nugent and Tyler } \\
\text { Lathem and Rodnan } \\
\text { Houpt and Ogryzlo } \\
\text { Snaith and Scott }\end{array}$ & $\begin{array}{l}1957 \\
1959 \\
1962 \\
1964 \\
1970\end{array}$ & $\begin{array}{l}\text { U.S.A. } \\
\text { U.S.A. } \\
\text { U.S.A. } \\
\text { Canada } \\
\text { U.K. }\end{array}$ & $\begin{array}{r}150 \\
6 \\
11 \\
30 \\
46\end{array}$ & $\begin{array}{l}7 \cdot 5 \\
6 \cdot 2 \\
6 \cdot 0 \\
5 \cdot 0 \\
3 \cdot 6\end{array}$ & $\begin{array}{r}61 \\
7 \\
10 \\
22 \\
46\end{array}$ & $\begin{array}{l}8 \cdot 7 \\
8 \cdot 5 \\
7 \cdot 5 \\
7 \cdot 0 \\
5 \cdot 8\end{array}$ \\
\hline
\end{tabular}


daily. The mean plasma level of uric acid in the present group of gouty patients $(7.9 \mathrm{mg} . / 100 \mathrm{ml}$.) is lower than the $9.0 \mathrm{mg} . / 100 \mathrm{ml}$. given in the study of Gutman and Yü (1957).

Clearance figures for both gouty and control subjects are lower than those found by other workers (Table). Gutman (1964) stated that 24-hr specimens, as used in the present study, usually give a lower figure than urine and blood specimens timed over short periods, as employed in the studies cited. However, our figures for glomerular filtration rate, as expressed by endogenous creatinine clearance, are not unusually low.

Values for the urinary uric acid: creatinine ratio for the gouty subjects (mean $0 \cdot 39 \pm 0 \cdot 1$ ) were very little different from those found in our control group (mean $0 \cdot 40 \pm 0 \cdot 1$ ). These figures are considerably lower than those given by Kaufman, Greene, and Seegmiller (1968) for patients with deficiency of the enzyme hypoxanthineguanine phosphoribosyltransferase either complete (mean $3 \cdot 19 \pm 1 \cdot 0$ ) or partial (mean $1.06 \pm 0.43$ ). They are, however, virtually identical with the figures given by these authors for patients with gout but no such enzyme deficiency.

It is known that there are many factors which regulate plasma levels of uric acid and which may therefore lead to hyperuricaemia (Scott, 1969; Healy and Hall, 1970). Studies of relatively large numbers of subjects, such as the present investigation, therefore have definite limitations, as one is probably dealing with a heterogeneous population in which various influences are operating. Available evidence, including the fact that uric acid clearance is appreciably reduced in gouty patients and also tends to be reflected by that of their close relatives (Scott and Pollard, 1970), indicates that it is those factors which relate to the renal handling of urate which will be of significance in most patients with gout.

\section{Summary}

Uric acid excretion and clearance were compared in 46 gouty patients and 46 control subjects. The mean plasma level of uric acid was $7.9 \mathrm{mg} . / 100 \mathrm{ml}$. in the gouty patients and $5.1 \mathrm{mg} . / 100 \mathrm{ml}$. in the controls. The corresponding figures for 24-hr urinary output were 514 and $479 \mathrm{mg}$. There was a significantly reduced renal clearance of uric acid in the gouty subjects $(3.6 \mathrm{ml} . / \mathrm{min}$.) compared with the controls $(5.8 \mathrm{ml} . / \mathrm{min}$.), indicating that factors bearing on the renal handling of urate are of importance in the majority of patients with gout.

We are indebted to Mrs. Hannelore Yablonsky who carried out the biochemical estimation; and to the Arthritis and Rheumatism Council for Research without whose aid this work would have been impossible.

\section{Discussion}

DR. J. A. BOYLE (Glasgow) I wonder if you are not comparing two different things here. You have measured the creatinine clearance and take this as an index of normal renal function, yet the secretion of urate is through the tubule. It would be interesting to know if tests of tubular function have been performed in both patients with gout and controls to see just how well matched they were with respect to tubular function rather than glomerular function.

DR. SNAITH We are at present looking into this aspect, but for the purposes of this particular investigation, especially as creatinine clearance has been compared before in a similar way, it was reasonable to limit ourselves to uric acid and creatinine clearance to make the point.

DR. J. S. LAWRENCE (Manchester) The important finding in this study is that uric acid clearance is significantly reduced in your gouty patients whereas increased production of uric acid is less common and is not significant. This agrees with findings in populations with very high uric acid levels such as the Filipinos investigated by Decker and his group in Seattle.

Did you notice whether hypertension was equally present in the overproducers and underexcretors, or whether it occurred only in those with diminished urate clearance?

DR. SNAITH We examined blood pressure in patients and controls. I do not think we can draw any really valid conclusions from these findings, since blood pressure figures should be taken repeatedly to assess the presence of true hypertension.

PROF. E. G. L. BYWATERS (Hammersmith) I should like to ask if the authors had looked separately at their gouty patients with a low clearance and those with a more normal clearance.

DR. SNAITH We did perform correlation coefficients on several of these parameters and there was no correlation.

\section{References}

EDWARDS, K. D. G., AND WHYTE, H. M. (1958) Aust. J. exp. Biol., 36, 383 (The measurement of creatinine in plasma and urine).

Evans, J. G., Prior, I. A. M., And Harvey, H. P. B. (1968) Ann. rheum. Dis., 27, 319 (Relation of serum uric acid to body bulk, haemoglobin, and alcohol intake in two South Pacific Polynesian populations).

Grahame, R., AND SCOTt, J. T. (1970) Ibid., 29, 461 (Clinical survey of 354 patients with gout).

Gutman, A. B. (1964) Amer. J. Med., 37, 833 (Editorial: Significance of the renal clearance of uric acid in normal and gouty man).

- AND Yü, T. F. (1957) Ibid., 23, 600 (Renal function in gout. With a commentary on the renal regulation of urate excretion, and the role of the kidney in the pathogenesis of gout). 
(1968) Ibid., 45, 756 (Uric acid nephrolithiasis).

, AND BERGER, L. (1969) Ibid., 47, 575 (Renal function in gout. III. Estimation of tubular secretion and reabsorption of uric acid by use of pyrazinamide (Pyrazinoic acid)).

Houpt, J. B., AND OGRYZLO, M. A. (1964) Arthr. and Rheum., 7, 316 (Peristence of impaired uric acid excretion in gout during reduced synthesis with allopurinol).

Healy, L. A., AND Hall, A. P., (1970) Bull. rheum. Dis., 20, 600 (The epidemiology of hyperuricemia).

Kaufman, J. M., Greene, M. L., AND Seegmiller, J. E. (1968) J. Pediat., 73, 583 (Urine uric acid to creatinine ratio-a screening test for inherited disorders of purine metabolism).

LATHEM, W., AND RODNAN, G. P. (1962) J. clin. Invest., 41, 1955 (Impairment of uric acid excretion in gout).

LidDle, L., Seegmiller, J. E., AND LASTER, L. (1959) J. Lab. clin. Med., 54, 903 (The enzymatic spectrophotometric method for determination of uric acid).

Nugent, C. A., AND TyLeR, F. H. (1959) J. clin. Invest., 38, 1890 (The renal excretion of uric acid in patients with gout and in nongouty subjects).

ScorT, J. T. (1969) Proc. roy. Soc. Med., 62, 851 (Causes of hyperuricaemia).

- AND Pollard, A. C. (1970) Ann. rheum. Dis., 29, 397 (Uric acid excretion in the relatives of patients with gout).

Seegmiller, J. E., Grayzel, A. I., LASTer, L., AND Liddie, L. (1961) J. clin. Invest., 40, 1304 (Uric acid production in gout).

Thompson, R. H. S., AND Wootron, I. D. P. (1970) 'Biochemical Disorders in Human Disease', 3rd ed., p. 274, Churchill, London. 